\title{
Value Creation of Business Incubator Functions: Economic and Social Sustainability in the COVID-19 Scenario
}

\author{
Cristina Lin-Lian ${ }^{1, *}$, Carmen De-Pablos-Heredero ${ }^{1,2} \mathbb{D}$ and José Luis Montes-Botella ${ }^{3}$ (D) \\ 1 Department of Business Economics (Administration, Management and Organization), \\ Applied Economics II and Fundamentals of Economic Analysis, Rey Juan Carlos University, \\ Paseo de los Artilleros s/n, 28032 Madrid, Spain; carmen.depablos@urjc.es \\ 2 ESIC Business \& Marketing School, Rey Juan Carlos University, Paseo de los Artilleros s/n, \\ 28032 Madrid, Spain \\ 3 Department of Applied Economy I, Rey Juan Carlos University, Paseo de los Artilleros s/n, \\ 28032 Madrid, Spain; joseluis.montes@urjc.es \\ * Correspondence: c.lin@alumnos.urjc.es
}

check for updates

Citation: Lin-Lian, C.; De-Pablos-Heredero, C.;

Montes-Botella, J.L. Value Creation of Business Incubator Functions:

Economic and Social Sustainability in the COVID-19 Scenario. Sustainability 2021, 13, 6888. https://doi.org/ $10.3390 /$ su13126888

Academic Editors: Roberta Costa and Marc A. Rosen

Received: 19 May 2021

Accepted: 15 June 2021

Published: 18 June 2021

Publisher's Note: MDPI stays neutral with regard to jurisdictional claims in published maps and institutional affiliations.

Copyright: (C) 2021 by the authors. Licensee MDPI, Basel, Switzerland. This article is an open access article distributed under the terms and conditions of the Creative Commons Attribution (CC BY) license (https:/ / creativecommons.org/licenses/by/ $4.0 /)$.

\begin{abstract}
Spain has encouraged support to sustain entrepreneurs in the COVID-19 pandemic. In this paper, the usefulness of the functions of business incubators regarding the social benefits derived from enhancing the sustainability of the entrepreneurial ecosystem is studied in the context of the COVID-19 scenario. Due to the lack of academic literature on the subject, an analysis based on the application of structural equation models (SEMs) has been carried out using a theoretical framework built and empirically validated using a representative sample of Spanish entrepreneurs. The results show that, according to stakeholders, the functionalities of business incubators were oriented to drive entrepreneurial initiatives to have highly positive effects on society. This research evidences that business incubators are key mechanisms to make entrepreneurship, growth and economic development more sustainable in society.
\end{abstract}

Keywords: entrepreneurship; business incubator functions; COVID-19; sustainability; benefit in society

\section{Introduction}

The entrepreneurial ecosystem is defined as a set of inter-agency and coordinated actors with the aim of enabling entrepreneurship in a given territory [1,2]. Isenberg highlights its thirteen components: leadership, governance, culture, success stories, human capital, finance capital, business organizations, educational institutions, infrastructure, economic clusters, networks, transport services and first clients [3]. These elements can work towards a culture oriented towards entrepreneurship, the availability of finance, the acquisition and development of human capital, new markets for products and services, and various institutional and infrastructure tools to support entrepreneurial initiatives [4-6]. These elements should be interconnected as they are mutually reinforced to promote an open context of innovation and entrepreneurship growth [3,7]. Feld, Acs et al. and Spigel consider that all entrepreneurs have access to the same resources, support entities and chances of success, but this, in practice, does not happen [2,4,5]. Below, two models are described that determine different keys to build an efficient business ecosystem.

The Babson Entrepreneurial Ecosystem Project considers six sets of variables: macro environment factors [1,2], general variables that influence the business environment, as well as specific variables that influence the creation of enterprises [1], a group in which the author highlights the existence of business incubators, as well as variables influencing the capacity to create a new business [2,5], factors influencing business dynamics and elements affecting economic growth [5].

The Elements Model in the Entrepreneurial Ecosystem Cycle of Lerma and Sequera, Stam and Isenberg is composed of nine elements: government, consumers, human capital 
(talent), market, financing, business culture, knowledge/academia, public and private organizations, and networks $[2,6]$. In both models, business incubators are among the dynamic elements of the entrepreneurial ecosystem aimed at creating economic and social value.

The main purpose of business incubators is to explore the most appropriate framework for the creation, development, and maturity of the business experiences of a designated area, establishing a context that increases the probability of success of the business [8]. They positively influence the entrepreneur's ecosystem and create value in society $[9,10]$. Therefore, business incubators are structures that participate in the ecosystem by providing business services with good knowledge quality and by identifying good practices in the delivery process [11].

The objective of this article is to evaluate whether the functions that are usually performed in the business incubators help to support the enterprises they host from the point of view of entrepreneur in the crisis situation caused by COVID-19.

While entrepreneurship and its relationship to economic and social growth has been extensively studied, there is a shortage of research focused on the economic and social sustainability of business incubators from the perspective of entrepreneurs [12]. This research will allow us to determine the opinions of the protagonists in the eco entrepreneurial system, the entrepreneurs, with regard to the capacity of business incubators to contribute to the sustainability of their projects and will offer the opportunity to promote regional entrepreneurship policies based on the usefulness of business incubators to create social value in a pandemic crisis scenario.

The article is divided into five parts. The first part focuses on the review of literature related to both the functions of business incubators and their sustainability, with a special emphasis on the COVID-19 situation. The second part presents the model that explains the perception of entrepreneurs regarding the influence of business incubators on the sustainability of the ecosystem and the formulated hypotheses. The third part, the methodology, includes the survey and the justification for the statistical analysis applied. The fourth part, the results, is dedicated to the validation of the model. Finally, the fifth part presents the discussion and conclusions.

\section{Literature Review}

\subsection{Impact of COVID-19 on Business Incubators and Entrepreneurial Activity}

The COVID-19 pandemic has caused a major health and economic crisis [13-15], which in turn has damaged the labor force and social welfare [16,17]. The Funcas report provides figures justifying the need to encourage business creation and entrepreneurship in order to sustain employment and revive the economy. It notes that one of the most profitable options is business incubators [18]. Among the economic consequences of the COVID-19 situation, the rise in unemployment in Spain stands out. The following figure (Figure 1) shows the trend in the number of unemployed people in recent months.

Despite the differences in numbers, in Spain and the European Union, the trend is the same, and they have remained more or less established until April 2020, when the first wave of COVID-19 broke out [19], and since April, the number of unemployed persons rose dramatically. In the European Union, it increased by 17.14\% from April 2020 to October 2020 and in Spain it increased by $12.91 \%$ in the same period. Both reached a peak in July 2020, which represents a growth of $16.59 \%$ in the European Union compared to July 2019 and in the case of Spain, $16.34 \%$ [15,17]. Figure 2 shows the number of households by number of unemployed in Spain. 


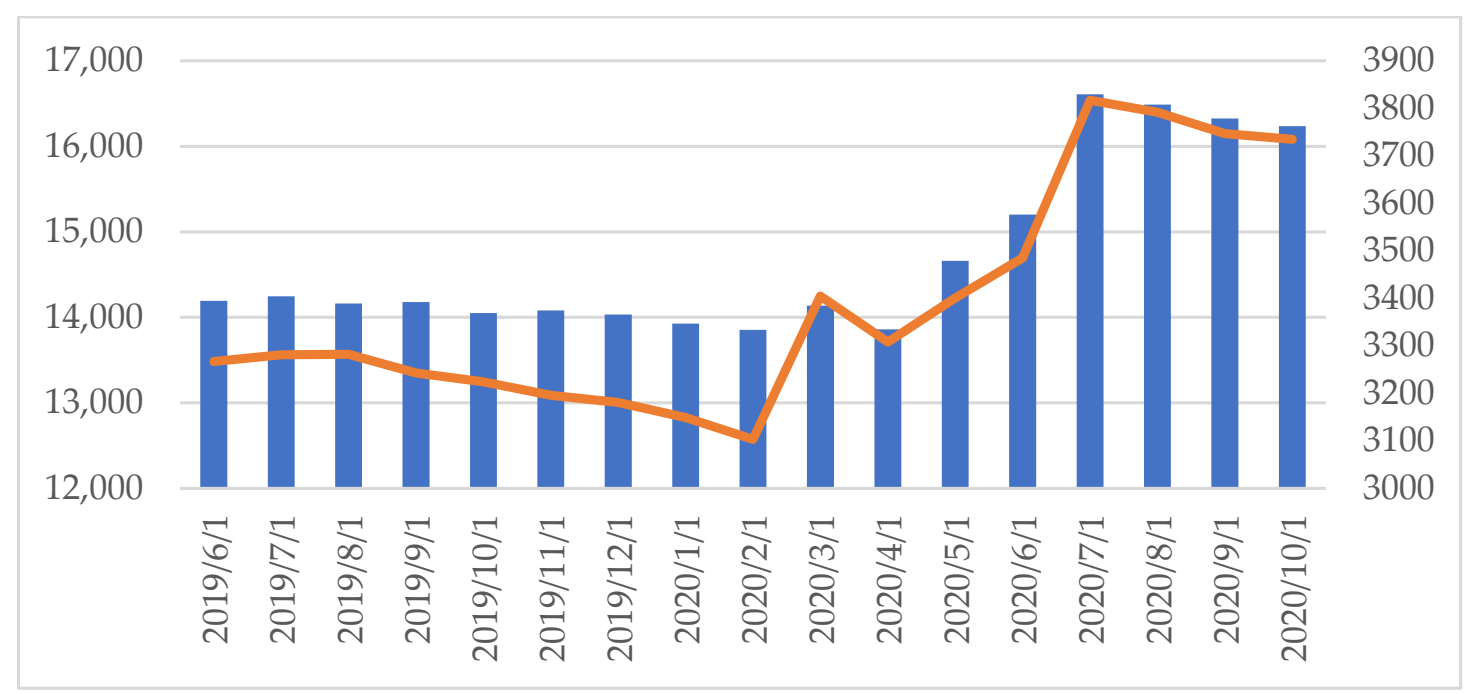

Figure 1. Unemployment trends in Spain and the EU (2019-2020). U.E. Spain.

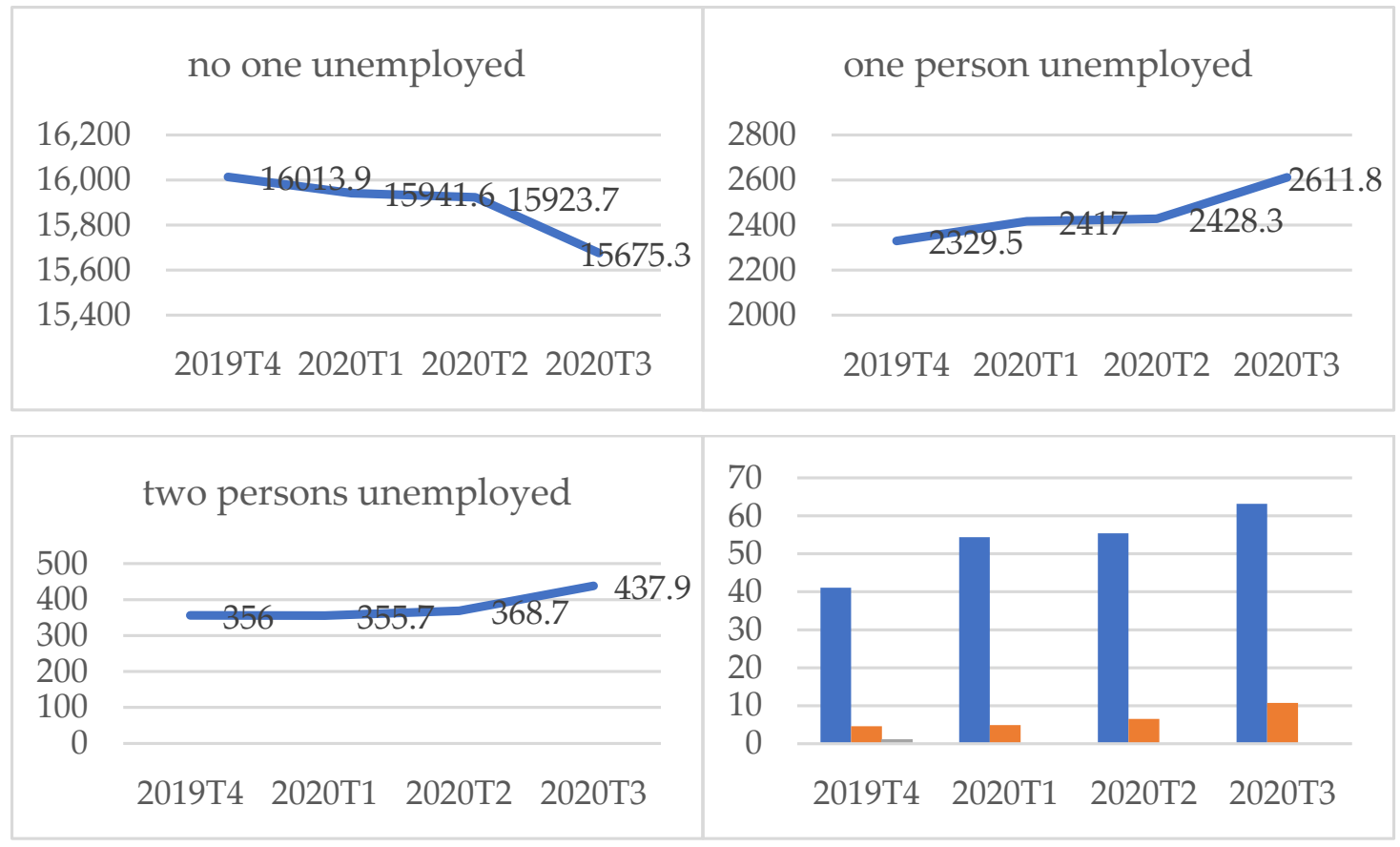

Figure 2. Number of households by number of unemployed in Spain (2019T4-2020T3) (thousands of households). ——three unemployed persons. __ four unemployed persons.

In the above graphs, we can see the increase in the number of unemployed persons in Spain per family per quarter and the number of households in Spain that did not experience an decreased in unemployment by $-2.26 \%$ from the fourth quarter of 2019 to the third quarter of 2020, which cover a total of 338.6 thousand dwellings. Families with one unemployed member have increased by $12.12 \%$, with two unemployed- $23 \%$, with three unemployed-53.77\%, with four unemployed-1.33\% [15,19]. The situation in which several people are unemployed per family aggravates the economic position and the need to earn money in to subsist. One of the best ways to acquire it is entrepreneurship [20,21]. Figure 3 shows people employed by brand of activity in the period 2019-2020. 


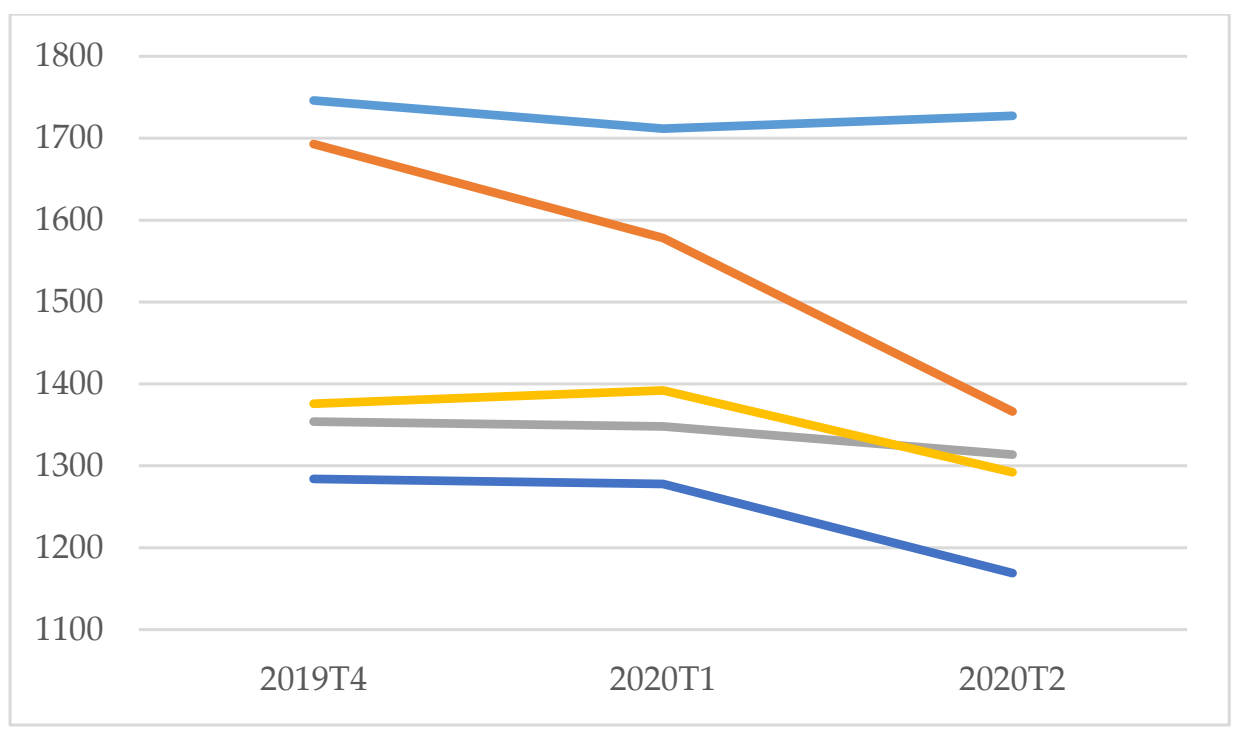

Figure 3. People employed by brand of activity (2019T4-2020T2) (thousand people). —-Construction. —- - Hospitality. _- Public Administration and Defense. _—Education. _— Health and Social Services Activities.

The two largest sectors of activity by wealth contributing to the economy in 2019 were: hospitality (tourist accommodation and catering) [20,22,23], which represented 20.9\% of the GNP, with a total of EUR 252.000 million [15,23], and construction, which represented $14 \%$ of Spain's GDP at the end of 2019 (a total of EUR 168.767 million). We note that both sectors suffered a large decline in the first two quarters of 2020, both in the number of jobs - in the construction sector, $-8.95 \%$, and in the hospitality sector, $-19.3 \%$-and in the Spanish GDP, not counting the other sectors. In the case of education, which has also suffered the effects of COVID-19, the loss for Spain was EUR 63,740.65 million, and the figures show that this trend is constantly worsening today $[15,19]$.

The above data indicate that the situation we are living in offers one of the best frameworks to be undertaken by necessity. Entrepreneurship out of necessity $[20,21,24]$ and business incubators can play a critical role in the economic and social reactivation and sustainability of entrepreneurial activity $[2,5,6]$.

\subsection{Hypotheses}

Business incubators are key elements for the development and sustainability of an efficient entrepreneurial ecosystem [9,24,25]. The development of a good network of business incubators is one of the most important challenges facing an economy to encourage entrepreneurial activity [26]. Among its functions is the reduction in costs of information, administration and training that are generated by entrepreneurial activity, facilitating entrepreneurs in the creation of companies, as well as making the possibility of entrepreneurship more accessible [27].

In business incubators, the entrepreneur is accompanied throughout the process, from the generation of the idea to the start-up of the business [20]. According to the administrator of the Business Incubator of the Chamber of Commerce of Santiago de Compostela, which occupies the first place of the preincubation centers of companies in Spain in the ranking Funcas 2019-2020, and the third place in the ranking of business incubators $[9,18]$, business incubators help entrepreneurs to create business ideas, select the most appropriate one, carry out paperwork and administrative formalities, conduct training and mentoring, and seek funding for all possible routes [18,28].

In a country, the generation of new businesses means economic growth and new jobs, which can be of two types: employer-employer (self-employment) and positions for potential employees [28]. In this process, business incubators play a very important role as 
mechanisms to encourage the creation of companies. According to a study carried out by the Madrid City Council from 2011 to 2019, business incubators of Madrid have created an average of 130 companies annually [29].

Entrepreneurs believe that business incubators not only drive the growth of new businesses, but help them grow and survive throughout their life cycles [18,30], and this in turn causes synergies between companies to improve the national economy [15,31]. Business incubators encourage new companies to carry out training actions to train people in entrepreneurial skills [24,32], support the implementation of a business plan $[8,28]$, provide advice and processing for the creation of a new company through an entrepreneur service point (PAE) [18,28] and offer support for new business initiatives through the provision of facilities and specialized consultancy for business incubators [18,28,33]. This leads to the formulation of the first hypothesis:

Hypothesis 1 (H1). Stakeholders believe that the actions taken by business incubators help to set up businesses.

Compared to the previous scenario, the creation of new companies leads to new jobs (self- or limited enterprise, not contracting, micro-enterprises, small enterprises, etc.) [9]. According to the Funcas report, a year and a half after creation, companies begin to hire workers to meet the company's growth and demand [9].

According to the entrepreneur's point of view, the functions of the business incubators mentioned below help enterprise creation with the aid of these entities to survive in the market and create more jobs [18,28], encourage the consolidation of new businesses by minimizing costs at the start of the activity, and strengthen the positions of entrepreneurs, creating a suitable environment for their business development without the need of large investments $[18,28,33]$.

Panorama Laboral [34] shows that business incubators are efficient tools for job creation $[9,29]$. GEM shows the impact that its incubation program has generated since 2009, highlighting the creation of 3120 direct and indirect jobs in just two years [35]. Considering previous arguments, here is the second hypothesis:

Hypothesis 2 (H2). Stakeholders believe that the functions of business incubators lead to an increase in employment.

Another benefit of business incubators is that they serve as a link between uncertainty and innovation. According to a previous analysis based on asking questions to entrepreneurs, business innovations need not be limited to products/services, but in many cases offer new business models and/or business ideas, thus creating new opportunities in today's markets [36]. Therefore, innovation can be produced by creating new products/services more adapted to the needs of customers or by launching new business models that are more productive or sustainable [36].

One of the main objectives of the public business incubators is to promote innovative companies [28], and there are even business incubators specially dedicated to this, as in the case of the public business incubator in Móstoles (Madrid) [37], a joint initiative of the Municipality of Móstoles with the Universidad Rey Juan Carlos and the Agency for the Development of Companies (Móstoles Desarrollo) [38], where of all the incubated companies, $80 \%$ are related to $R \& D[37,39]$. Taking into account previous considerations, here is the formulation of the third hypothesis:

Hypothesis 3 (H3). Stakeholders believe that the functions of business incubators have a positive impact on innovation.

Carree and Thurik describe that entrepreneurs are people inclined to work longer hours and more efficiently, since their income is directly linked to their work [40]. The support of incubators increases the chances of survival of companies as their productivity 
increases [41,42]. In views of entrepreneurs, this is mainly due to the following functions of the business incubators according to the authors Ebbers and Blanco and the Funcas report: carrying out networking activities (relationship) [28,43] and acceleration of high potential projects in free co-working spaces $[18,28]$. This is the fourth hypothesis:

Hypothesis 4 (H4). Stakeholders believe that business incubator functions increase productivity.

Economic growth without social growth turns into undesirable effects such as population displacement, violence, youth marginalization, indifference, unemployment, etc. [44], which in turn hinders a country's productivity and competitiveness and results in less attraction for investment [45]. Therefore, the entrepreneur must be a cohesive agent in the national ecosystem [46], as he is responsible for bringing about a change in the business management model of a given geographical location [47]. In addition, proper training in the social responsibilities they have as agents of the ecosystem is the key to their being socially responsible to society, and in this, business incubators play a major role, especially with the two functions of advice and tutoring in all areas of entrepreneurship, including the social and legal aspects for the development of all kinds of ideas that are intended to be implemented $[9,48]$ and strengthening entrepreneurial capacity by creating an appropriate environment for business development by solving, at all times, the problems entrepreneurs may have in the different administrative, social, and economic areas, and always advising them on the best options after analyzing the cases by experts $[18,28,33]$. Therefore, as Blanco points out [28], business incubators have a major role socially, because thanks to them the entrepreneur stops being a risky adventurer who travels alone in the business world to be a driver of the economy [28]. This leads to the formulation of the fifth hypothesis:

Hypothesis 5 (H5). Stakeholders believe that the functions of business incubators increase social cohesion.

While business incubators are not economically profitable at the outset, as they need financial support and public investment to start operations, in particular public business incubators [20], they do have a social return. It can be measured by the activity developed by the entrepreneurs and how it provides the general government-via taxes-with yields superior to those invested in the incubators $[49,50]$. According to the study carried out by Sentana in the 40 business incubators of Valencia, EUR 2.8 are collected through taxes for each euro spent on the start-up of a business incubator [30].

This economic development is mainly linked to two functions of the business incubators mentioned by Blanco, Hansen, Chesbrough, Nohria and Sull and, additionally, in the INE, GEM, and Funcas reports, the experiences of entrepreneurs are considered: incubators increase the survival rate of enterprises during their first years of life by minimizing the costs at the start of the activity and counselling and monitoring all the time they are incubated, as well as when they graduate $[18,28]$. They contribute to employment generation, both wage-earning and through self-employment $[9,15,51]$. Therefore, the increase in the number of entrepreneurs and start-ups, which in turn are driven by business incubators, stimulates the growth and economic development of a given area by increasing and facilitating the movement of capital, resources and capacities in the area, which makes a country's national economy better positioned compared to other countries [52].

Previous considerations bring us to the formulation of the sixth hypothesis:

Hypothesis 6 (H6). Stakeholders believe that the functions of business incubators influence economic and social sustainability.

In summary, we can affirm that the main purpose of the business incubators is to explore the most appropriate framework for the creation, development and maturity of 
business experiences in a certain area, providing a series of services to its customers $[53,54]$ in a context that increases the likelihood of success and survival of the business $[8,55]$.

\section{Material and Methods}

\subsection{Methodology}

To validate the above hypotheses, a structural equation analysis with latent variables (SEM) was performed on a representative sample of entrepreneurs. SEM is a statistical technique that is appropriate for dealing with intangible assets. Structural equation models allow one to describe the multiple relationships between variables and, in this way, the hypotheses can be validated empirically [56]. It also allows one to estimate and evaluate the relationship between non-observable variables, the so-called latent variables that are measured through observable variables. Compared to other multivariate methods, where the latent variables can only be represented by a single measurement, multiple measurements are used in SEM to control the specific measurement error of each variable, allowing the researcher to evaluate and test the validity of each measured variable and theoretical models. Statistical analyses were performed using the method of partial least squares (PLS) with SmartPLS3 software [57].

\section{Sample}

The sample is composed of 194 entrepreneurs in Spain. Spain is the leader in the number of active business incubators in Europe [12]. The sample is composed of a population of entrepreneurs with residence in Spain who know the business incubators. The geographical area is Spain. The methodology used is online closed surveys. The method of measuring is Likert scale. To build the model, Smart PLS has been chosen. The sample, by simple random sampling, is composed of 194 entrepreneurs, 56 of whom are located in business incubators, which means $28.86 \%$ of the sample (of the 194 respondents, $60.31 \%$ (117 respondents)) know the business incubators and, of these, $47.86 \%$ have been in business incubators.

The survey mainly studied the impacts of different functions of business incubators on economic and social aspects from the entrepreneurs' opinions. Data were collected from 7th April 2020 to 19th September 2020 according to the following schedule (Table 1).

Table 1. Methodology schedule, date and number of surveys collected.

\begin{tabular}{|c|c|c|c|}
\hline & Date & Number of Surveys & Description \\
\hline Publication on the advisory website & From 7 th to 10 th April & 48 & $\begin{array}{l}\text { We have spoken with the Advisory } \\
\text { Administrator located in Madrid, } \\
\text { where he has worked since } 2016 \text { to } \\
\text { the present day, to publish the } \\
\text { survey in a non-working place, } \\
\text { with the right to publish it during a } \\
\text { week (from Tuesday to Friday). }\end{array}$ \\
\hline \multirow{3}{*}{$\begin{array}{l}\text { Electronic contact with } \\
\text { different entrepreneurs }\end{array}$} & From 17th to 27th April & \multirow{3}{*}{74} & \multirow{3}{*}{$\begin{array}{l}\text { Contacted different entrepreneurs } \\
\text { to ask them for help with the } \\
\text { dissemination of the survey. }\end{array}$} \\
\hline & From 6th to 30th May & & \\
\hline & From 3rd to 30th June & & \\
\hline \multirow{2}{*}{$\begin{array}{l}\text { Contact with consulting companies } \\
\text { and training activities and } \\
\text { well-known entrepreneurs }\end{array}$} & From 3rd to 28th July & \multirow{2}{*}{66} & \multirow{2}{*}{$\begin{array}{l}\text { Contact with two companies in } \\
\text { Madrid: one for advice to students } \\
\text { and another for training activities. }\end{array}$} \\
\hline & From 7th to 30th August & & \\
\hline \multirow[t]{2}{*}{$\begin{array}{l}\text { Contact with entrepreneurs facilitated } \\
\text { by acquaintances }\end{array}$} & $\begin{array}{l}\text { From 9th to } \\
\text { 19th September }\end{array}$ & 6 & \\
\hline & & Total: 194 & \\
\hline
\end{tabular}

Questionnaires represent one of the most widely used methods in social research, since they allow obtaining extensive information from primary sources [41]. The survey was conducted online due to its ease of distribution and wide reach [41], especially in unforeseen 
situations such as the current one caused by the COVID-19, but other means of contact with entrepreneurs have also been maintained, such as telephone and online meetings.

The measurement of the questions in the survey was carried out through a Likert scale [44]. The scales used in the questionnaire have already been validated by other studies $[12,58]$. This work is part of a broader research where the effects and impacts of business incubators on entrepreneurship are studied. Questions have been taken from a longer questionnaire. These questions are divided into two blocks: functions of the incubators (block 1 ) and social benefits of the business incubators. The table (Table 2) draws inspiration from previous studies on the functions of business incubators measured in this research (block 1). The functions are listed in the left column and the works that inspired the function are included in the right column.

Table 2. Functions of business incubators and bibliographic sources that have inspired them.

\begin{tabular}{lcc}
\hline Function & References \\
\hline Promotion of entrepreneurship & {$[9,48]$} \\
Advice and tutoring for the development of all kinds of ideas that are intended to be implemented & {$[9,18,34]$} \\
Carrying out training actions to train all people in various entrepreneurial skills & {$[24,32,39]$} \\
Support in the preparation of the Business Plan (pre-incubation service) & {$[8,28]$} \\
Advice and processing for the incorporation of the company through the Attention Point to the Entrepreneur (PAE) & {$[18,28]$} \\
Implementation of networking (relationship) activities & {$[28,43]$} \\
Project incubation: co-working space plus offices & {$[9,43,52]$} \\
Acceleration of high potential projects, also in free co-working spaces & {$[18,28,43,52]$} \\
Support new business initiatives through the provision of facilities and specialized consultancy & {$[18,28,33]$} \\
Strengthen entrepreneurship by creating an enabling environment for business development & {$[18,28,33]$} \\
Encouraging the consolidation of new businesses by minimizing costs at the start of business & {$[52]$} \\
Increasing the survival rate of enterprises during their first years of life & {$[18,28]$} \\
Contribute to the generation of employment, both wage-earning and through self-employment & {$[9,15,18,51]$} \\
\hline
\end{tabular}

In Table 3, different studies that relate entrepreneurship through business incubators and different benefits for society (block 2) are presented. They have been the inspiration for building the questionnaire.

Table 3. The main literature in business incubators and benefits for entrepreneurs and society.

\begin{tabular}{lc}
\hline Main Topic & References \\
\hline Entrepreneurship & {$[9,15,18,28,35,55]$} \\
Increase in employment & {$[9,34,35]$} \\
Increase in innovation & {$[2,9,18,20,34,36]$} \\
Increase in productivity & {$[40-42]$} \\
Increase in cohesion & {$[9,18,20]$} \\
Promoting growth and economic development & {$[18,30,49,50]$} \\
\hline
\end{tabular}

For each block, a set of variables was defined. Therefore, we have 2 sets: those related to the role of business incubators (fBI) and those related to the benefits of incubators in society (ImpBI). Additionally, the values obtained in the descriptive analysis for each variable are included.

\section{Results}

\subsection{Descriptive Results}

The surveys were conducted among Spanish entrepreneurs, operating mainly in the service sector: "legal, financial, insurance, accounting, bookkeeping, auditing and tax consultancy activities" (31.07\%), "marketing and advertising" (15.53\%), and "educational and training activities and services" $(12.62 \%)$, while the product sector: "wholesale or retail sale of mail order or internet products" represents only $4.37 \%$ of the sample. 
Of the number of subcontracted employees, 38.14\% of the 194 respondents were selfemployed, $8.25 \%$ of them had one employee, $28.35 \%$ had two employees and only $25.26 \%$ of these had three or more employees. In total, $74.74 \%$ of SMEs surveyed had fewer than two employees.

Of the 194 surveys obtained, 60.31\% knew the business incubators (117 companies); therefore, these are the companies considered in the analysis. The assessment was made on a Likert scale, with 1 representing that the respondent does not consider the factor important, 2 that the factor is considered unimportant, 3 that the factor is considerably important, 4 that the factor is important, and 5 that the factor is very important.

The majority of respondents agree that the most important functions are: to promote the consolidation of new companies by minimizing costs at the beginning of the activity (3.65 out of 5$)-89.75 \%$ of entrepreneurs score this as more than 3 ; increase the survival rate of companies ( 3.63 out of 5$)-86.32 \%$ of respondents rated this as more than 3 ; support in the preparation of the business plan (3.53 out of 5) - the majority of the respondents, $86.32 \%$ of the entrepreneurs, valued this as more than 3 ; and advice and process for the incorporation of the company through the Attention Point to the Entrepreneur (3.53 out of 5$)-84.61 \%$ of the respondents valued this as more than 3 . This makes sense because promoting the consolidation of new businesses by minimizing costs and better planning with the implementation of the business plan increases the survival rate of businesses [39]; another function highly valued by entrepreneurs is the administrative function of advising and processing for the incorporation of the company, which helps entrepreneurs who want to start their own business but do not know how or have no economic resources to do so. In return, entrepreneurs mention that the role of advice and mentoring for the development of all kinds of ideas that are intended to be launched (2.98 out of 5) is less important as most firms usually enter the business incubator with a clear idea of entrepreneurship.

The three most important impacts of incubators for entrepreneurs are: firstly, the creation of businesses, with an average of 3.38 out of $5.83 .76 \%$ of the 117 respondents, which they rated as more than 3 on the Likert scale; second, promoting economic growth and development, with an average of $3.21 / 5$ and $76.93 \%$ of the respondents rating it as more than 3; and thirdly, an increase in business productivity-an average of 3.15/5 and $70.09 \%$ of respondents rated this as more than 3. Other impacts of business incubators on society are also considered important by entrepreneurs, having a lower impact score of 2.92 out of 5 and an average impact of 3.145, which shows that business incubators have an important impact on society from the point of view of entrepreneurs.

\subsection{Model and Scenario Analysis}

The proposed model (Figure 4) was estimated by bootstrap (5000 samples) using the Smart PLS 3 program and was evaluated in two stages [48,59]. In the first, the measurement model was evaluated and, in the second, the structural model was evaluated.

With respect to the measurement model, all the weights of the standardized indicators have values greater than 0.70 with values $p \leq 0.000$, which reveals the strong significance of the indicators $[60,61]$ (Figure 4 ).

The construct "function" presents a reliability of 0.945 , which is higher than 0.70 , considered acceptable in the literature. Similarly, the Cronbach alpha [60] takes a value of 0.936, indicative of an excellent reliability level. The convergent validity evaluated with the AVE takes the value of 0.568 , which is higher than the commonly accepted threshold of 0.50 , while the discriminating validity was evaluated by the Fornell-Larcker criterion [61], which took a value for the construct of 0.754 , which is higher than the commonly used threshold.

For the evaluation of the structural model, the significance of all values with a $p$-value less than 0.000 was first verified, resulting in the acceptance of all the proposed hypotheses. The adjusted $R^{2}$ of the different constructs took values between 0.286 and 0.490 , which are acceptable within these types of research in social sciences. The size of the effect is strong with values between 0.408 and 0.972 , which are clearly superior to the value 0.35 threshold. The influence (on a normalized scale of 0 to 1 ) of the latent variable/construct (function) 
on societal impacts, reliability and acceptance or rejection of hypotheses is presented in Table 4.

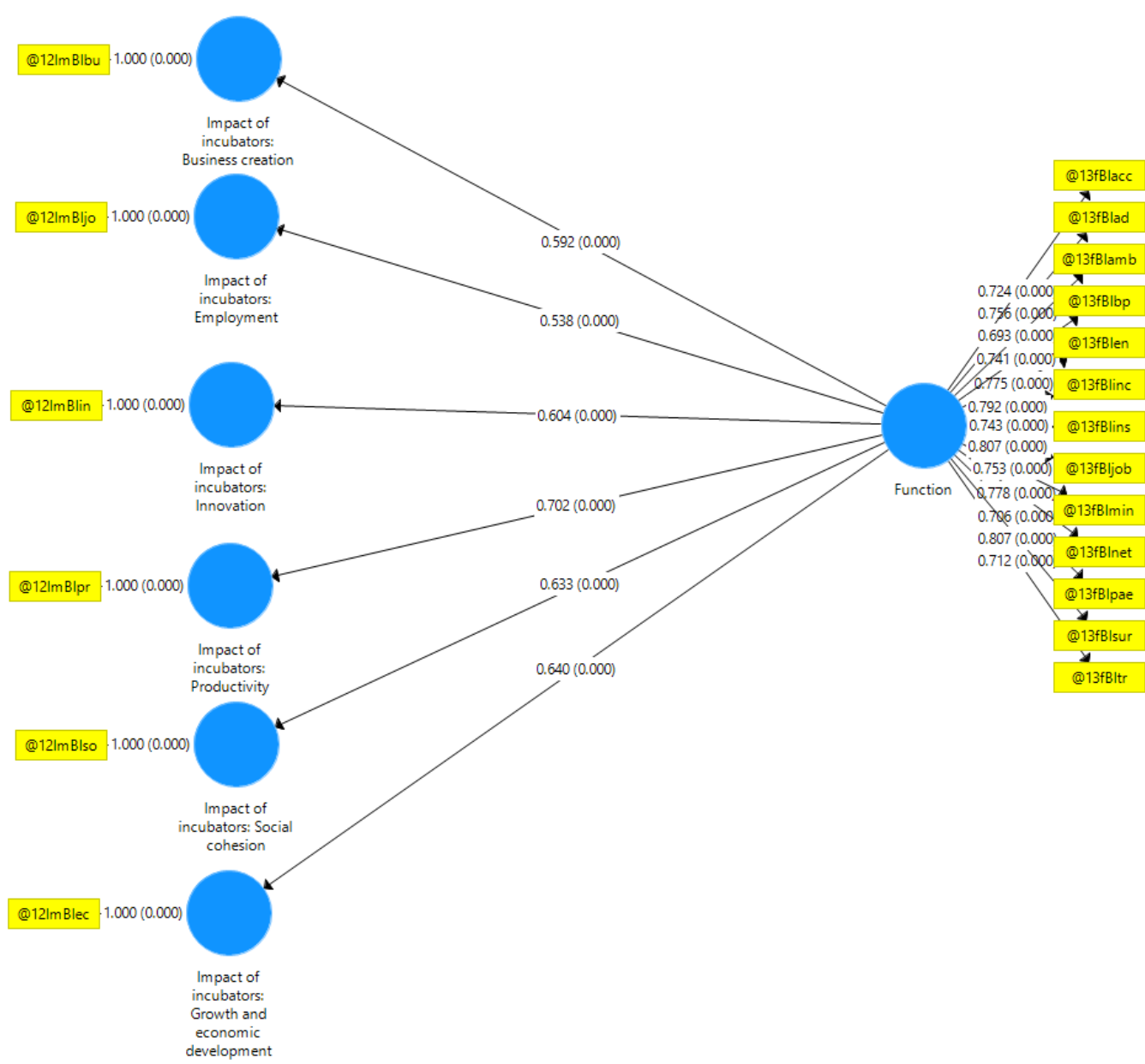

Figure 4. Statistical model of structural relationships between the functions of business incubators and impacts on society.

Table 4. Acceptance/rejection of assumptions by parameter value and $p$-value.

\begin{tabular}{cccc}
\hline Hypotheses & Standard Indicator & $p$-Value & $\begin{array}{c}\text { Acceptance/Rejection } \\
\text { of the Hypothesis }\end{array}$ \\
\hline H1: Function -> ImBIbu & 0.592 & 0.000 & Acceptance \\
H2: Function -> ImBIjo & 0.538 & 0.000 & Acceptance \\
H3: Function -> ImBIin & 0.604 & 0.000 & Acceptance \\
H4: Function -> ImBIpr & 0.702 & 0.000 & Acceptance \\
H5: Function -> ImBIso & 0.633 & 0.000 & Acceptance \\
H6: Function -> ImBIec & 0.640 & 0.000 & Acceptance \\
\hline
\end{tabular}

H1. Stakeholders believe that the functions performed by business incubators help to set up businesses $(\beta=0.592, p<0.001)$. Hypothesis confirmed.

The relationship between these two variables is positive and statistically significant. Higher scores in the functions of business incubators are associated with a greater impact on business creation.

$\mathrm{H} 2$. Stakeholders believe that the functions of business incubators lead to an increase in employment $(\beta=0.538, p<0.001)$. Hypothesis confirmed.

The relationship between these two variables is positive and statistically significant; higher scores in the functions of business incubators are associated with a greater impact on the increase in employment in society. 
H3. Stakeholders believe that the functions of business incubators have a positive impact on innovation $(\beta=0.604, p<0.001)$. Hypothesis confirmed.

The relationship between these two variables is positive and statistically significant; higher scores in the functions of business incubators are associated with a higher impact with regard to increasing the innovation in society.

H4. Stakeholders believe that business incubator functions increase productivity $(\beta=0.702, p<0.001)$. Hypothesis confirmed.

The relationship between these two variables is positive and statistically significant. Higher scores in the functions of business incubators are associated with a greater impact on the increased productivity in society.

H5. Stakeholders believe that the functions of business incubators increase social cohesion $(\beta=0.633, p<0.001)$. Hypothesis confirmed.

The relationship between these two variables is positive and statistically significant. Higher scores in the functions of business incubators are associated with a more positive impact on increasing the social cohesion of society.

H6. Stakeholders believe that the functions of business incubators influence economic and social sustainability $(\beta=0.640, p<0.001)$. Hypothesis accepted.

The relationship between these two variables is positive and statistically significant; higher scores in the functions of business incubators are associated with a more positive impact on increasing the social cohesion of society.

All the hypotheses raised by the literature review are validated with a great reliability, represented by a $p$-value of 0.000 (less than 0.005 ), and influence is confirmed by the $p$-value which goes from moderately high to high (from 0.592 to 0.702 ), all of which are above 0.5.

The greatest impact of the functions of business incubators (latent variable) is on the increase in the productivity of society from the point of view of entrepreneurs $(0.702$, high influence), followed by influence on economic growth and development $(0.640$, moderately high influence). The influence of the functions of the business incubators on the increase in social cohesion $(0.633$, moderately high influence) is confirmed in the third place. In fourth place, the impacts on innovation (0.604, moderately high influence) are confirmed. In fifth place, business incubators impact the creation of companies $(0.592$, moderately high influence), and finally, business incubators impact on the employment increase $(0.538$, moderately high influence). Therefore, we can affirm that the model shows that the functions of the business incubators have direct impacts and are moderately high in all the model presented.

\section{Discussion}

Through this research, the impacts of the functions of business incubators aimed at maintaining entrepreneurship sustainability in society have been analyzed from the entrepreneur's perspective. From the empirical perspective, the model presented is aligned with the previous literature review and the results show that all hypotheses are validated at a high level of significance $(p<0.000)$.

The functions of business incubators are: implementation of actions to train people in entrepreneurial skills $[24,32]$, support in the performance of the business plan $[8,28]$ advice and procedures for the setting up of a new business through an entrepreneur service point (PAE) $[18,28]$ and support for new business initiatives through the provision of facilities and specialist consultancy for business incubators $[18,28,33]$, described by Seoane and García [55], creating value.

Studies carried out by Madrid City Council and Funcas [18,29] show that incubators play a very important role as mechanisms to encourage business start-ups. This is in line with the results of our model on hypothesis one, but our study also shows that business incubators are not only effective in the creation of companies in Madrid, but they are effective throughout the Spanish territory. As studies by the Madrid City Council, Funcas and Panorama Laboral show, the creation of new companies is directly related to new job creation and job growth. These variables are directly and positively related, although these 
studies are limited to the geographical limit of Madrid [9,18,29,34]. Therefore, we observe that the literature on the positive impact of business incubators on job creation coincides with the results of our model in relation to hypothesis 2 .

Blanco comments that business incubators play a very important role in all areas related to the creation of innovative companies. Just as innovative companies have great difficulty in obtaining financing due to their risky bets, since it is very difficult to obtain financing for something that does not yet exist, nor for of which there is no experience, business incubators can serve as the link between uncertainty and innovation [18,39], and according to the reports published by the Municipality of Móstoles and Móstoles Business Incubator, analyzing the companies incubated in the Móstoles Business Incubator (Madrid) from 2011 , more than 80 companies [28,29,37,39], $85 \%$ of them, are innovative companies according to Ramírez, director of the Móstoles business incubator [39].

Entrepreneurs are people inclined to work longer hours and more efficiently, since their income is directly linked to their work [40-42]. According to the study carried out by Carree and Thurik on the basis of the analysis of the GEM database and GDP growth in 36 countries, which was oriented to study the effect of business activity on economic growth, there is a direct and positive relationship between both variables [40], as well as a study conducted by the Eight Roads Ventures, one of the world's largest venture capital companies, in 2018, on top entrepreneurial partnerships from interviews with 313 founders and co-founders of technology companies in Denmark, France, Germany, Spain, Sweden and the United Kingdom, with a minimum income of one million dollars; the results show that entrepreneurs are more ambitious not only with economic issues, but they are also not happy with the current situation. The results of the study show that for young people under 30, the main motivation for starting a business was that they see a problem that is not being solved properly, they have sufficient knowledge about a concrete subject and believe that they can solve the problem better than anyone else, so they undertake solving it to benefit society. However, when entrepreneurs are over 35, they start a business because they are not happy with the work or job situation they are in and want to change. What is common between both profiles is that they are willing to work more because they have the motivation to change the current situation in which they are in [62], which shows that the increase in entrepreneurs and companies is directly related to increasing the productivity of society. This is in line with the results of our surveys on hypothesis 4 to Spanish entrepreneurs, showing that the functionalities of business incubators increase the productivity of society.

In addition, the entrepreneur plays a role as a social cohesive agent in the national ecosystem $[46,47]$. The study carried out by Eight Roads Ventures shows that entrepreneurs present a high cohesion with both themselves and society, as the companies they founded effectively must not only take care of customers, but they should also be taking care of their teams and the culture of the company, since the capturing of talent and creation of an excellent team is the only way for a company to grow to a large scale. We conclude that one of the best ways to capture and retain talent is to have an adequate culture and social responsibility [62]. Entrepreneurs can therefore play an important role socially [28], and in this respect business incubators can play an important role as assessors and/or trainers of incubators $[30,49,50]$. Therefore, according to the results of our study on hypothesis 5 , stakeholders believe that business incubators play an important role in social cohesion.

Therefore, we can state in relation to hypothesis 6 that, according to stakeholders' perspectives, the increase in the number of entrepreneurs and new companies, driven in turn by business incubators, as we have argued in the above scenarios, increases the sustainability of the entrepreneurial ecosystem by stimulating the growth and economic development of a given area, as they increase and facilitate the movement of capital, resources and capacities in the area, which puts a country's national economy in a better position compared to other countries. 
As a result of this analysis, the research question is answered: "Do business incubators, through their functions aimed at making the system more sustainable, create value in society?" The answer is yes from the perspective of stakeholders.

\section{Conclusions}

The results of this research show the importance of the functions of business incubators aimed at making the entrepreneurship ecosystem more sustainable.

The hypothesis of the relationship between the functions of business incubators and profits in the creation of companies (H1) is based on a high degree of compliance in our study with the previous results and confirms findings of the preliminary analysis. Concerning the relationship between the functions of business incubators and increased employment in society $(\mathrm{H} 2)$, the study carried out by GEM shows that its incubation program has created 3120 direct and indirect jobs in just two years (from 2009 to 2011) [35].

Regarding the relationship with innovation growth (H3), it is confirmed that business incubators, from the entrepreneur perspective, encourage the creation of new innovative companies in Madrid, which is in line with the results of our research on scenario 3-the incubators cause a positive impact on the innovation, the difference is that our study is limited to the Spanish territory and the results are based on the information that comes directly from the opinion of the entrepreneurs.

Concerning the relationship between the functions of business incubators and increased productivity (H4), the hypotheses related to the increase in social cohesion (H5) and with the promotion of economic growth and development $(\mathrm{H} 6)$ are supported. The results obtained in our study agree with the results of previous studies $[28,30,40-42,46,47,49,50,62]$. Therefore, in summary, we can affirm that improving the functions of business incubators, as the most appropriate framework for the creation, development and maturity of business experiences in a certain area, is effective [28].

As the main implications, the identification of the different functions of the business incubators that have an impact on society could lead to improvements in those functions in the business incubators and in turn improve the impacts on the different segments of society. Entrepreneurs' points of view should also be considered to adjust the functions of business incubators to their real needs in difficult scenarios, such as the one we are facing as a consequence of COVID-19 scenario. Considering entrepreneurs' perspectives, open innovation practices oriented to improving the services provided by business incubators should be facilitated. The limitations found in this research basically emerge from the methodology used-surveys presented to entrepreneurs. The questions and answers raised certain limitations. The target audience also presents profile limitations, a limited sample and national geographic boundary. This paper establishes a general framework on the functions and impacts of business incubators on society, but a more in-depth study of other specific and socio-demographic variables is required to complete this study.

Author Contributions: Conceptualization and methodology, all authors. Formal analysis, software, data curation, data processing, C.L.-L. and J.L.M.-B.; statistical analysis, C.L.-L. and J.L.M.-B.; validation and investigation, C.L.-L. and C.D.-P.-H.; supervision, J.L.M.-B. and C.D.-P.-H.; data acquisition, C.L.-L. All authors were involved in developing, writing, commenting, editing, and reviewing the manuscript. All authors have read and agreed to the published version of the manuscript.

Funding: This research received no external funding.

Institutional Review Board Statement: Not applicable.

Informed Consent Statement: Not applicable.

Acknowledgments: We would like to thank all the entrepreneurs who have provided data, support and time and have made possible the preparation of this work, and the Rey Juan Carlos University and public business incubators in Madrid who have offer the ideas and the resources to start with my work in the field of business incubators. Thanks to OPENINNOVA Research Group for their support to this article. 
Conflicts of Interest: The authors declare no conflict of interest.

\section{References}

1. Malecki, E.J. Entrepreneurship and entrepreneurial ecosystems. Geogr. Compass 2018, 12, e12359. [CrossRef]

2. Stam, F.C.; Spigel, B. Entrepreneurial ecosystems. USE Discuss. Pap. Ser. 2016, 16, 1-15.

3. Isenberg, D.J. How to start an entrepreneurial revolution. Harv. Bus. Rev. 2010, 88, 40-50.

4. Feld, B. Startup Communities: Building an Entrepreneurial Ecosystem in Your City; John Wiley \& Sons: Hoboken, NJ, USA, 2020.

5. Acs, Z.J.; Stam, E.; Audretsch, D.B.; O'Connor, A. The lineages of the entrepreneurial ecosystem approach. Small Bus. Econ. 2017, 49, 1-10. [CrossRef]

6. Isenberg, D. The Entrepreneurship Ecosystem Strategy as a New Paradigm for Economy Policy: Principles for Cultivating Entrepreneur-Ship. Presentation at the Institute of International and European Affairs, Dublin, Ireland, 2011, 1-13. Available online: http:/ / www.innovationamerica.us/images/stories/2011/The-entrepreneurship-ecosystem-strategy-for-economicgrowth-policy-20110620183915.pdf (accessed on 2 February 2021).

7. Brush, C.G. Exploring the concept of an entrepreneurship education ecosystem. In Innovative Pathways for University Entrepreneurship in the 21st Century; Emerald Group Publishing Limited: Bingley, UK, 2014.

8. García, A.V.; Seoane, F.J.F. Experiencias regionales en viveros de empresas. Rev. Estud. Reg. 2015, 102, 177-208.

9. Blanco, F.J.J.; Ackerman, B.V.; Polo, C.G.O.; Fernández, M.T.F.; Santos, J.L. Los Servicios Que Prestan los Viveros de Empresas en España; Ranking 2018/2019. Funcas: Madrid, Spain, 2019. Available online: https:/ /www.funcas.es/libro/los-servicios-queprestan-los-viveros-de-empresas-en-espana-ranking-2018-2019-noviembre-2018/ (accessed on 2 February 2021).

10. Acs, Z.J.; Autio, E.; Szerb, L. National systems of entrepreneurship: Measurement issues and policy implications. Res. Policy 2014, 43, 476-494. [CrossRef]

11. Alderete, R.Y.; Flores, L.E.; Mariño, S.I. Diagnóstico de Gestión del Conocimiento en una organización pública. In Proceedings of the XI Simposio Argentino de Informática en el Estado (SIE)-JAIIO, Córdoba, Spain, 4-8 September 2017; Volume 46, pp. 4-8.

12. García-Ochoa, C.P.; De-Pablos-Heredero, C.; Jiménez, F.J.B. How business accelerators impact startup's performance: Empirical insights from the dynamic capabilities approach. Intang. Cap. 2020, 16, 107-125. [CrossRef]

13. Enfermedad Coronavirus (COVID-19). Organización Mundial de la Salud, 2021. Available online: https://www.who.int/es/ health-topics / coronavirus\#tab=tab_1 (accessed on 20 February 2021).

14. World Health Organization. Coronavirus Disease (COVID-19) Pandemic. 2021. Available online: https://www.who.int/ emergencies/diseases/novel-coronavirus-2019 (accessed on 20 February 2021).

15. Instituto Nacional de Estadística (INE). 2021. Available online: https:/ /ine.es/ (accessed on 20 January 2021).

16. Banco de España (Eurosistema). Acciones Relacionadas Con el COVID-19. 2021. Available online: https://www.bde.es/bde/es/ Home/Noticias/covid-19/ (accessed on 22 January 2021).

17. Gobierno de España: Ministerio de Sanidad. Enfermedad Por Nuevo Coronavirus, COVID-19. 2021. Available online: https: / / www.mscbs.gob.es/ (accessed on 18 January 2021).

18. Blanco, F.J.J.; Polo, C.G.O.; Fernández, M.T.F.; Santos, J.L.; de Esteban, D.E. Los Servicios que Prestan los Viveros de Empresas en España. Ranking 2020/2021. Funcas: Madrid, Spain, 2020. Available online: https:/ /www.funcas.es/libro/los-servicios-queprestan-los-viveros-y-aceleradoras-de-empresas-en-espana-ranking-2020-2021/ (accessed on 8 February 2021).

19. European Statistical Recovery Dashboard: Eurostat. 2021. Available online: https://ec.europa.eu/eurostat/cache/recoverydashboard/ (accessed on 20 February 2021).

20. Roundy, P.T.; Bradshaw, M.; Brockman, B.K. The emergence of entrepreneurial ecosystems: A complex adaptive systems approach J. Bus. Res. 2018, 86, 1-10. [CrossRef]

21. Davila, A.; Foster, G.; Li, M. Reasons for management control systems adoption: Insights from product development systems choice by early-stage entrepreneurial companies. Account. Organ. Soc. 2009, 34, 322-347. [CrossRef]

22. De-Pablos-Heredero, C.; Montes-Botella, J.L.; García-Martínez, A. Sustainability in smart farms: Its impact on performance. Sustainability 2018, 10, 1713. [CrossRef]

23. World Travel and Tourism Council. Economic Recovery Will be Powered by Travel \& Tourism Sector Says WTTC. 2019. Available online: https:/ / wttc.org/ (accessed on 18 March 2021).

24. Ferreiro Seoane, F.J.; Mendoza Moheno, J.; Hernández Calzada, M.A. Contribución de los viveros de empresas españolas en el mercado de trabajo. Contaduría Adm. 2018, 63, 1-16. [CrossRef]

25. Grimaldi, R.; Grandi, A. Business incubators and new venture creation: An assessment of incubating models. Technovation 2005, 25, 111-121. [CrossRef]

26. Tenca, F.; Croce, A.; Ughetto, E. Business angels research in entrepreneurial finance: A literature review and a research agenda. J. Econ. Surv. 2018, 32, 1384-1413. [CrossRef]

27. Bermejo, J.M.; De Pablos, C. An analysis of the Spanish Science and Technology system. Procedia Technol. 2013, 9, 511-517. [CrossRef]

28. Blanco, F.J.; Guseva, V.; López, C.M. Los viveros de empresas. Economistas 2012, 30, 45-52.

29. Ayuntamiento de Madrid. Viveros de Empresas. 2021. Available online: https:/ / www.madrid.es / (accessed on 12 February 2021).

30. Sentana, E.; González, R.; Gascó, J.; LLopis, J. The social profitability of business incubators: A measurement proposal. Entrep. Reg. Dev. 2017, 29, 116-136. [CrossRef] 
31. De-Pablos-Heredero, C.; Fernández-Valero, G.; Blanco-Callejo, M. Supplier Qualification Sub-Process from a Sustained Perspective: Generation of Dynamic Capabilities. Sustainability 2017, 9, 730. [CrossRef]

32. Ferreiro, F.J. Mujer y emprendimiento. Una especial referencia a los viveros de empresas en Galicia. RIPS Rev. Investig. Políticas Sociológicas 2013, 12, 81-101.

33. Qianqian, R.; Xindong, W. Application of Data Envelopment Analysis in Efficiency Assessment of Business Incubator: Taking Sci-Tech Business Incubators in Beijing as Example. Technol. Econ. 2011, 7, 37-43.

34. Universidad Complutense de Madrid. Panorama Laboral de la Comunidad de Madrid. 2018. Available online: https://www. ucm.es/aedipi/panorama-laboral-de-la-comunidad-de-madrid (accessed on 4 February 2021).

35. Global Enterpreneurship Monitor. Global Enterpreneurship Monitor 2019/2020 Global Report. 2020. Available online: https: / / www.gemconsortium.org/report/gem-2019-2020-global-report (accessed on 25 January 2021).

36. Blanco-Callejo, M.; de Pablos-Heredero, C. Co-innovation at Mercadona: A radically different and unique innovation model in the retail sector. J. Bus. Retail. Manag. Res. 2019, 13, 326-341.

37. Ayuntamiento de Mostoles. Mostoles Desarrollo: Viveros de Empresas. 2021. Available online: https://www.mostoles.es/ (accessed on 12 February 2021).

38. Ayuntamiento de Mostoles. Vivero de Empresas del Ayuntamiento de Móstoles. 2021. Available online: https:// viveroempresasmostoles.es/ (accessed on 12 February 2021).

39. Lin, C.L. Business incubators: Mechanisms to boost business innovation capacity. Analysis of business incubators in the Community of Madrid. Esic Market Econ. Bus. J. 2020, 51, 73-103. [CrossRef]

40. Carree, M.A.; Thurik, A.R. Understanding the role of entrepreneurship for economic growth. Pap. Entrep. Growth Public Policy 2003, 1005, 1-11.

41. Kuhlthau, C.C.; Maniotes, L.K.; Caspari, A.K. Guided Inquiry: Learning in the 21st Century: Learning in the 21st Century; Abc-Clio: Santa Barbara, CA, USA, 2015.

42. El Hussein, M.; Hirst, S.; Salyers, V.; Osuji, J. Using grounded theory as a method of inquiry: Advantages and disadvantages. Qual. Rep. 2014, 19, 1-15.

43. Ebbers, J.J. Networking behavior and contracting relationships among entrepreneurs in business incubators. Entrep. Theory Pract. 2014, 38, 1-23. [CrossRef]

44. Thompson, I. Definición de Encuesta. Promonegocio. 2010. Available online: https://www.promonegocios.net/mercadotecnia/ encuestas-definicion.html (accessed on 29 January 2021).

45. Mateus, J.R.; Brasset, D. La globalización: Sus efectos y bondades. Econ. Desarro. 2002, 1, 65-77.

46. Hernández, A.F.S. El rol del empresario en la cohesión social. Criterio Libre 2011, 9, 127-154. [CrossRef]

47. Ortiz, P.G.; Millán, A.M.J. Emprendedores y empresa. In La Construcción Social del Emprendedor; Universidad de Murcia: Murcia, Spain, 2011.

48. Anderson, J.C.; Gerbing, D.W. Structural equation modeling in practice: A review and recommended two-step approach. Psychol. Bull. 1988, 103, 411. [CrossRef]

49. Redondo, M.; Camarero, C. Social Capital in University Business Incubators: Dimensions, antecedents and outcomes. Int. Entrep. Manag. J. 2019, 15, 599-624. [CrossRef]

50. Ascigil, S.F.; Magner, N.R. Business incubators: Leveraging skill utilization through social capital. J. Small Bus. Strategy 2009, 20, 19-34.

51. Hansen, M.T.; Chesbrough, H.W.; Nohria, N.; Sull, D.N. Networked incubators. Harv. Bus. Rev. 2000, 78, 74-84.

52. Moriset, B. Building New Places of the Creative Economy. The Rise of Coworking Spaces; HAL Archives-Ouvertes: Lyon, France, 2013.

53. Gallego Gómez, C.; De Pablos Heredero, C. Gestión de las relaciones con el cliente (CRM) y BIG DATA: Una aproximación conceptual y su influencia sobre el valor de los datos aplicados a la estrategia de venta. Dyna 2017, 92, 274-279. [CrossRef]

54. Pinheiro de Lima, O.; Breval Santiago, S.; Rodríguez Taboada, C.M.; Follmann, N. Una nueva definición de la logística interna y forma de evaluar la misma. Ingeniare Rev. Chil. Ing. 2017, 25, 264-276. [CrossRef]

55. Seoane, F.J.F.; García, A.V. Los viveros de empresas como instrumento para el emprendimiento. In Proceedings of the Actas de la

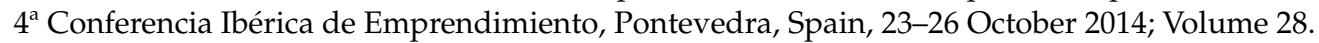

56. Hair, A.; Anderson, R.; Tatham, R.L.; Black, W. Multivariate Data Analysis; Kennesaw State University: Kennesaw, GA, USA, 2001; Volume 5.

57. Ringle, C.M.; Wende, S.; Becker, J.M. SmartPLS 3 [Computer Software]. SmartPLS GmbH 2015. Available online: http://www. smartpls.com (accessed on 30 April 2021).

58. García-Ochoa, C.P.; de Pablos Heredero, C.; Jiménez, F.B. The effects of business accelerators in new ventures' dynamic capabilities. Harv. Deusto Bus. Res. 2021, 10, 127-145. [CrossRef]

59. Chin, W.W. The Partial Least Squares Approach to Structural Equation Modelling. Mod. Methods Bus. Res. 1998, $295,295-336$.

60. Cronbach, L.J. Coefficient Alpha and the Internal Structure of Tests. Psychometrika 1951, 16, 297-334. [CrossRef]

61. Fornell, C.; Larcker, D.F. Evaluating Structural Equation Models with Unobservable Variables and Measurement Error. J. Mark. Res. 1981, 18, 39-50. [CrossRef]

62. Emprendedores. Eight Roads Ventures lanza un Fondo de 304 Millones de Euros Para 'Start Up' en Crecimiento. 2018. Available online: https://www.expansion.com/expansion-empleo/emprendedores/2018/03/20/5ab0d2a246163fa40e8b4621. html (accessed on 26 April 2021). 